\title{
ON OCCURRENCE, HABITAT SPECIFICITY AND NATURAL HISTORY OF ADULT TIGER BEETLES (COLEOPTERA: CARABIDAE: CICINDELINAE) NEAR MANAUS, CENTRAL AMAZONIA, AND KEY TO THE LARVAE OF TIGER BEETLE GENERA
}

\section{Joachim ADIS ${ }^{1}$, Wilfried PAARMANN ${ }^{2}$, Maristela A. AMORIM ${ }^{3}$, Erik ARNDT ${ }^{4}$, Claudio R. V. da FONSECA ${ }^{5}$}

\begin{abstract}
Over a seven year period from 1991 to 1997, 22 species of tiger beetles, representing nine genera, were recorded near Manaus, Brazil. In the whitewater floodplains along the Rio Solimões-Amazonas (Ilha de Marchantaria), three diurnal species inhabit inundation forests and six species (two diurnal, four nocturnal) live in open areas. Data on their natural history and adaptation to living conditions in floodplains are presented. Fifteen species were located on non-flooded uplands (Reserva Florestal A. Ducke). Five diumal species inhabit the forest floor, two species are canopy dwellers, and eight species (seven diurnal, one nocturnal) live in open areas on whitesand or laterite. Only one species, Pentacomia lacordairei, was found in both floodplain and upland forests, A key to the larvae of tiger beetle genera located near Manaus is presented.
\end{abstract}

Key words: Tiger beetles, floodplains, várzea, terra firme, Amazon, Neotropics.

Sobre a Ocorrência, Especifidade de Habitat e História Natural de Cicindelídeos (Coleoptera: Carabidae: Cicindelidae) Perto de Manaus, Amazônia Central, e Chave para Identificação dos Gêneros de Cicindelídeos.

RESUMO - Durante um período de sete anos (1991-1997), 22 espécies de cicindelídeos, representando 9 gêneros, foram encontradas perto de Manaus, Brasil. Nas várzeas ao longo do Rio Solimões-Amazonas (Ilha de Marchantaria), três espécies diurnas habitam às florestas inundáveis e seis espécies (duas diurnas, quatro noturnas) vivem nas áreas abertas. Apresentase dados sobre sua história natural e suas adaptações às condições de vida nas áreas alagáveis. Quinze espécies foram localizadas na terra firme (Reserva Florestal A. Ducke). Cinco espécies diurnas habitam o chão da floresta, duas espécies a copa de árvores, e oito espécies (sete diurnas, uma noturna) vivem em áreas abertas sob areia branca ou sob laterita. Somente uma espécie, Pentacomia lacordairei, foi encontrada nas florestas inundáveis e da terra firme. Apresenta-se uma chave para os gêneros das larvas de cicindelídeos localizadas perto de Manaus.

Palavras-chave; Cicindelideos, áreas inundáveis, várzea, terra firme, Amazônia, Neotrópicos.

1 Max-Planck-Institute for Limnology, Tropical Ecology Working Group, Postfach 165, D-24302 Plön, Germany.

2 Fachhochschule Hildesheim/Holzminden, Fachbereich Forstwirtschaft und Umweltmanagement, Büsgenweg 1A, D-37077 Göttingen, Germany.

3 Projeto INPA/MAX-PLANCK, Instituto National de Pesquisas da Amazônia (INPA), Caixa Poastal 478, 69.011-970 Manaus/AM, Brazil.

4 Anhalt University of Applied Sciences, LOEL, Strenzfelder Alleee 28, D-06406 Bernburg, Germany.

5. Instituto National de Pesquisas da Amazônia (INPA), CPEN, Caixa Postal 478, 69.011-970 Manaus/AM, Brazil. 


\section{INTRODUCTION}

Since August 1991, we have studied the tiger beetles of the Manaus area to understand the mechanisms that cause and maintain their high diversity in Central Amazonia (cf. Linsenmair, 1990).

Cicindelinae represent an appropiate taxon for this purpose. Adults are (1) taxonomically known: More than 2000 species are described worldwide, 184 from Brazil (Pearson \& Cassola, 1992), and at least 24 species occur in the Manaus area (Tab. 1). (2) The biogeographical distribution of tiger beetles is well known and species specific. Thus many species may be appropriate indicators that characterize ecosystems of open areas and of forests, (3) They occur worldwide but specialization as reflected by endemism is high; at least $50 \%$ of the Brazilian species are endemic to Brazil (Pearson \& Cassola, 1992). Tiger beetles are (4) potential control agents of insect pests: species common of rice paddies in India and Peru may prove to be effective control agents, e.g. of mole crickets (Gryllotalpa; Hudson et al., 1988; Pearson, 1988).

\section{In this first contribution we} present data on occurrence, habitat specificity and natural history for the cicindelid species from two of our main study areas near Manaus, Brazil: (1) on Ilha de Marchantaria, an island in the whitewater floodplain (seasonal várzea) of the Rio Solimões-Amazonas and (2) at Reserva Florestal A. Ducke, a forest reserve on non-flooded upland (terra firme). (3) In addition we present comparative data on the cicindelids inhabiting an inundation forest at Lago Janauarí, a mixed (black-white) water floodplain (seasonal igapó \& várzea) located between the Rio Negro and the Rio Solimões.

Our study areas near Manaus are subject to a rainy season (DecemberMay: average precipitation $1,550 \mathrm{~mm}$ ) and a period of low precipitation

Table 1. Species of tiger beetles (Cicindelinae) sampled in whitewater floodplains (seasonal várzea) of the Rio Solimões-Amazonas and in non-flooded uplands (terra fïme) near Manaus, Central Amazonia, Brazil.

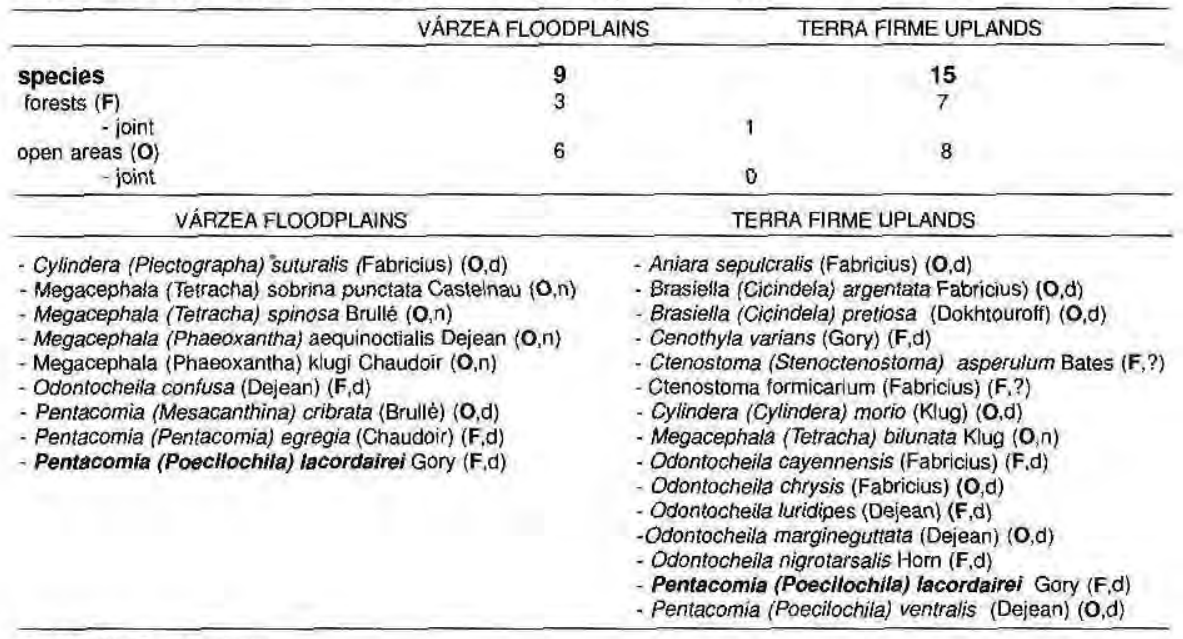

$\mathbf{F}=$ forests, $\mathbf{O}=$ open areas

$\mathrm{d}=$ diurnal, $\mathrm{n}=$ nocturnal 
(June-November (= "dry season"): average precipitation $550 \mathrm{~mm}$, but every month has some rain; cf. Ribeiro \& Adis, 1984).

\section{STUDY SITES}

\section{Whitewater floodplains (seasonal várzea)}

The study sites were located on Illha de Marchantaria $\left(03^{\circ} 15^{\prime} \mathrm{S}, 59^{\circ} 58^{\prime} \mathrm{W}\right)$. It is the first island in the Rio Solimões upstream of the confluence with the Rio Negro. It consists of riverborn sediments, predominantly montmorillonite, and is about 5000 years in age. The main sampling site of the inundation forest was located at the upper Lago Camaleão which was annually inundated $5.6 \pm 1.5$ months ( $24.0 \mathrm{~m}$ a.s.l.; $\mathrm{n}=95$ years) and up to a height of about $5.5 \mathrm{~m}$. Trees reached $28 \mathrm{~m}$ in height and carried few epiphytes. Pseudobombax munguba (Mart. ; Zucc.) Dugand (Bombacaceae) dominated the upper canopy, which was relatively open. The very thin litter layer on the ground was unfavourable for a rich soil fauna (cf. Adis 1997). Most organic material and leaves were either glued together by annually deposited river sediments, and/or were partly lost to strong currents during inundation. More information on the study area, the flora and the terrestrial invertebrates are given by Adis (1987, 1992), Irion et al. (1983), Junk (1997), Klinge et al. (1995) and Prance (1979).

\section{Mixedwater floodplains (seasonal igapó \& várzea)}

The sampling site at Lago Janauari $\left(03^{\circ} 20^{\prime} \mathrm{S}, 60^{\circ} 17^{\prime} \mathrm{W}\right)$ was situated on a strip of land between the Rio Negro and the Rio
Solimões, about $10 \mathrm{~km}$ south of Manaus. It has a mean annual inundation period (aquatic phase) of $3.1 \pm 1.6$ months ( $26.3 \mathrm{~m}$ a.s.1.; $\mathrm{n}=95$ years) and up to a height of about $3 \mathrm{~m}$. The region was influenced by blackwater of the Rio Negro during low water-level and by whitewater of the Rio Solimões during the high water period. The soil consisted of clay, predominantly montmorillonite, due to alluvial deposits of the Rio Solimões. The study site represented an ecotone, i.e. the flora and terrestrial invertebrates of the seasonal várzea as well as the seasonal igapó, and occasional faunal representatives of the non-flooded upland forest (cf. Adis \& Righi 1989, Adis \& Schubart 1984, Adis et al. 1996, Amaral et al. 1997, Erwin 1983, Morais et al. 1997a,b).

\section{Non-flooded uplands (terra firme)}

This study site was located at Reserva Florestal Adolpho Ducke ("Reserva Ducke"; 02 55'S, 59'59'W). This forest reserve is located $26 \mathrm{~km}$ northeast of Manaus on the ManausItacoatiara highway and covered by 90 $\mathrm{km}^{2}$ of mostly undisturbed rainforest. It belongs to the National Institute for Amazonian Research (INPA) at Manaus and represents one of the most intensively studied upland forest sites in Central Amazonia (e.g. Harada \& Adis, 1997; Penny \& Arias, 1982; Prance, 1990; Ruokaleinen et al., 1994). The soil in the primary forest supported a $2-3 \mathrm{~cm}$ thick humus layer $\left(\mathrm{A}_{\mathrm{o}}\right)$, interspersed with fine roots, and a thin, surface covering of leaf-litter. Around the field station, bare open areas, either of whitesand or laterite (yellow latosol), and grass-grown open areas are found (Fig. 2). 


\section{CICINDELINAE ON ILHA DE MARCHANTARIA (SEASONAL VÁRZEA)}

\section{Occurrence}

The water level of the Rio Solimões-Amazonas near Manaus fluctuates $10 \mathrm{~m}$ on average throughout the year. During high-water, vast areas near the river are flooded to a depth of several meters for five to seven months. The seasonal periodicity of this monomodal flood pulse (Junk, 1997; Junk et al., 1989) causes adaptations in terrestrial invertebrates of the Central Amazonian floodplain, referred to as "survival strategies", These are of ecoethological, ecophysiological and morphological nature
(Adis, 1997).

Nine cicindelid species were located on Marchantaria Island (Tab. 1). Their adult beetles, except Megacephala spinosa, can be identified with the keys provided by Pearson (1985) and Rodríguez et al. (1994). Three diurnal species inhabit the inundation forest (Fig. 1: OC, PE, PL). Six species, two diumal (CS, PC) and four nocturnal (MA, MK, MP, MS), live in open areas. Four of them are found on the bare, mostly sandy, sometimes clayey, beach (CS, PC, MP,MS). The other two species (MA, MK) inhabit the ascendig grassgrown area behind the beach (mainly composed of annual and perennial aquatic grasses, e.g. Echinochloa polystachia, Paspalum repens; cf. Junk \& Piedade,

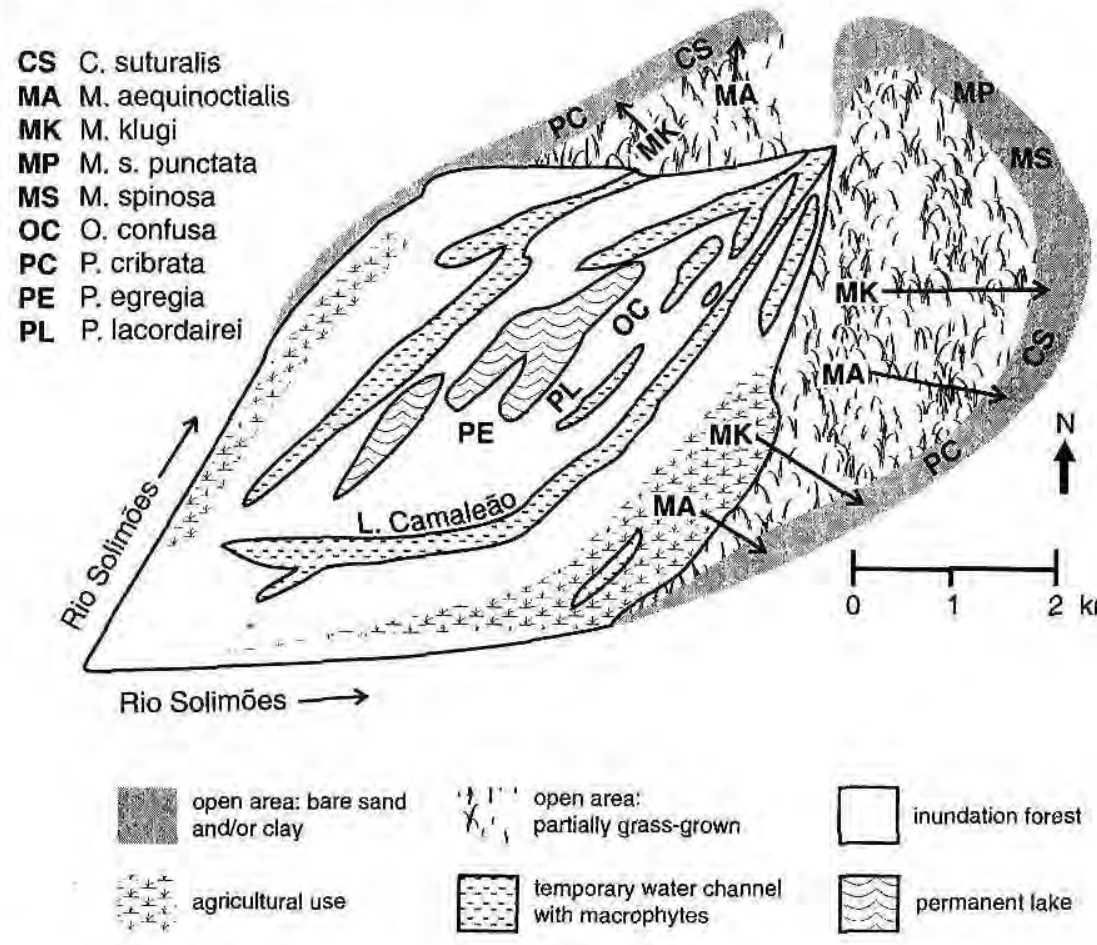

Figure 1. Species of tiger beetles (Cicindelinae) found on Itha de Marchantaria, the first island in the Rio Solimôes near Manaus, Central Amazonia, Brazil. 


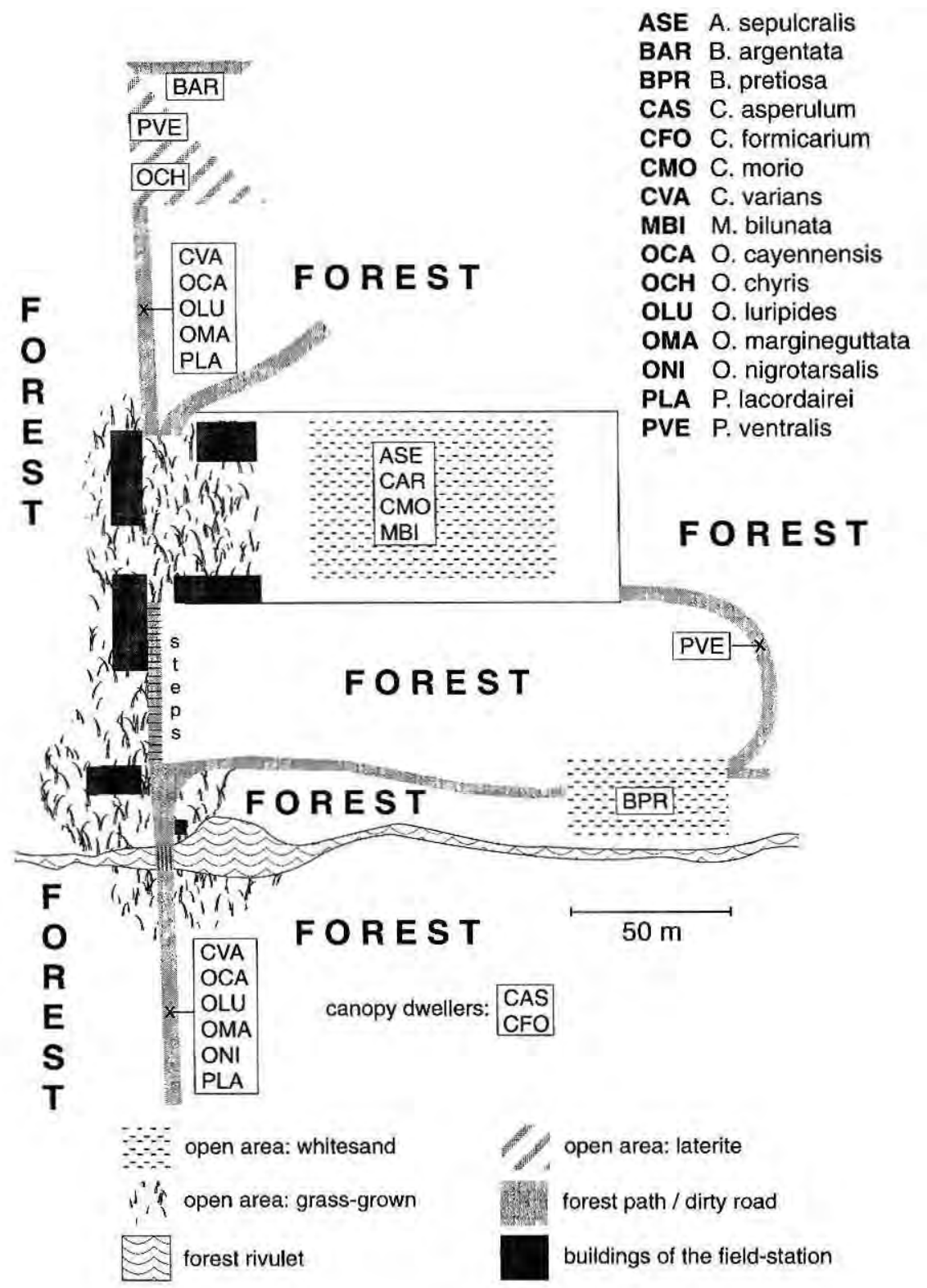

Figure 2. Species of tiger beetles (Cicindelinae) occurring in the vicinity of the field station at the Adolpho Ducke forest reserve (Reserva Ducke) near Manaus, Central Amazonia, Brazil. 
1997) and the more elevated parts of the island (mostly used for agricultural purposes). The adult beetles forage on the beach as well (cf. Fig. 1).

\section{Natural history}

\section{Cylindera suturalis}

This small species (body length $\leq 10 \mathrm{~mm}$ ) lives along sandy beaches of fresh and salt waters. It is widespread through South America and recorded from the Carribean Islands to southern Brazil. Based on differences in its elytral pattern, several forms have been described (cf. Freitag \& Barnes, 1989; Nunez et al., 1994; Pearson, 1985; Pearson \& Huber, 1985; Rodriguez et al., 1994; Wiesner, 1992). The form present in Central Amazonia seems to be hebraea (Klug). The three larval instars have been described by Arndt et al. (1997).

Near Manaus, C. suturalis is generally found on sandy beaches and banks, often on wet sediments, of the Rio Solimões-Amazonas and at the mouth of the Rio Negro. Adult beetles are diurnal, mostly "running-active" (Adis, 1982) and forage at the edge of the water. Adult Ephydridae (Hydrochasma sp., Discocerini, Diptera; det. W. Mathis) represent a favoured prey. When being disturbed, however, the adult beetles rápidly fly away, often towards dryer sand areas several meters distant from the river. Here they dig themselves into the sand with only the abdomen or solely the head being apparent. The complex pattern of white maculations on their elytra blends in with dry light-coloured sand and represents camouflage. According to Pearson \& Anderson (1985) adult beetles roost inside the base of leaf sheats of river-edge grass, 25-35 $\mathrm{cm}$ above the ground. C. suturalis can easily be bred (Amorim \& Adis, unpublished). First laboratory data indicate, that the development from the egg to the emerging beetle is about 4 months. Females deposit their eggs in sandy and clayey soil, but larvae readily move to sandy substrate after hatching. In the field, the diurnal larvae are mostly found in moist sand at the border of temporary pools along the beach or close to the river, but not in clayey sediments. It is unknown in which stage of development $C$. suturalis passes the aquatic phase and both life cycle and possible adaptations deserve further studies.

\section{Megacephala aequinoctialis}

This large species (body length $\leq 20 \mathrm{~mm}$ ) is widespread through South America. It is recorded from French Guyana, Venezuela, Ecuador, Peru, CoIombia, Bolivia, Brazil and Argentine (Nuñes et al., 1994; Pearson, 1985; Pearson \& Huber, 1985; Rodriguez et al., 1994 Wiesner, 1992). In Amazonia, M. aequinoctialis is generally found on sandy beaches and banks of rivers, often together with $M$. klugi. Huber (1994) suggested to place this species in the genus Phaeoxantha (Tab. 1).

On Marchantaria Island $M$. aequinoctialis occurs only sporadically (= "M. sp." in Ribeiro et al., 1996). The adult beetles are nocturnal, soil-dwelling, mostly "running-active" (Adis, 1982) despite being fully winged, and of solitary behaviour. They are mostly found in the higher parts of the island (Fig, 1) from where they come when 
foraging on the beach.

Adult beetles pass the day in individual burrows, like $M$. klugi.

The larvae, their habitat and the stage of development in which $M$. aequinoctialis passes the aquatic phase are still unknown.

\section{Megacephala klugi (Fig. 3c)}

This is one of the largest species of tiger beetles in South America (body length $\leq 26 \mathrm{~mm}$ ), generally found on sandy beaches and banks of Amazonian rivers. It is recorded from Venezuela, Ecuador, Peru, Colombia, Bolivia and Brazil (Nuñes et al., 1994; Pearson, 1985; Pearson \& Huber, 1985; Rodríguez et al., 1994; Wiesner, 1992). Huber (1994) suggested to place this species in the genus Phaeoxantha (Tab. 1).

Near Manaus, M. klugi is found along the Rio Solimões-Amazonas (Ribeiro et al., 1996; Fig. 1). The three larval instars have been described by Putchkov \& Arndt (1997).

The adult beetles are nocturnal, soil-dwelling, mostly "running-active" (Adis, 1982), univoltine and of solitary behaviour. During the terrestrial phase (August/September-March/April), animals pass the day in individual burrows up to $50 \mathrm{~cm}$ in depth and which are usually built before dawn. Upon exposure to sun light they generally retreat to their burrows by running or occasionally flying away (M.O. de A. Ribeiro \& M. Zerm, personal observation). Field studies on Marchantaria Island (Adis et al., in preparation) showed that adult beetles and larvae of $M$. klugi inhabit the higher parts of the open sandy floodplain, regardless if it is partially grass-grown or used for agriculture (Fig. 1). Larvae and beetles frequently feed on nocturnal crickets (Hemigryllus sp., Eneopteridae; det. L. Dessutter-Grandcolas). The larvae are mainly nocturnal and found in clusters. The diameter of their tunnel opening (Tab. 2) is enlarged to accomodate the larger size of the head capsule after each moult. Thus the numbers of each of the three larval stages in species specific colonies can be determinded readily. The first larval instar lasts about 4 weeks, the second instar 6-10 weeks. Field observations and flooding experiments in the laboratory showed, that larvae of the third instar enter a dormancy inside their tunnel in up to $1 \mathrm{~m}$ depth prior to the aquatic phase. They become active and start to open their tunnel entrances 3-12 weeks after the flood waters have receded. The development from the egg to the emerging beetle lasts 9-13 months. No adult beetles are found during the aquatic phase, except in

Table 2. Measurements of larval instars in Megacephala klugi.

\begin{tabular}{lccc}
\hline & LI & L II & L III \\
\hline Diameter of tunnel opening $(\mathrm{mm})$ & $2.5-3.0$ & $4.5-5.7$ & $8.2-9.5$ \\
Head width of larvae $(\mathrm{mm})$ & $2.32-2.48$ & $3.04-4.17$ & $5.63-6.54$ \\
Body length of larvae $(\mathrm{mm})$ & $12-17$ & $19-23$ & $29-36$ \\
Number of larvae & $\mathrm{n}=3$ & $\mathrm{n}=14$ & $\mathrm{n}=30$ \\
\hline
\end{tabular}


years when the higher parts of the island are not inundated. First beetles of the new generation emerge only few weeks after the aquatic phase has ended (in August/September), most of them, however, with the beginning of the rainy season (from December onwards). At night, the adult beetles frequently come to the wet sandbelt along the river and hunt for soft-bodied arthropods, together with $M$. aequinoctialis, $M$. sobrina punctata. and $M$. spinosa. Some animals stay at the beach up to several days, hiding in the individual burrows during the day. Their potential predators are nocturnal wading birds (see $M$. s. punctata).

\section{Megacephala sobrina punctata (Fig.3b)}

This relatively large species (body length $\leq 18 \mathrm{~mm}$ ) is generally found on sandy beaches and banks of Amazonian rivers. It is recorded from Peru, Brazil and Bolivia (cf. Pearson, 1985; Pearson \& Huber, 1985; Rodríguez et al., 1994; Wiesner, 1992). Huber (1994) suggested to place this species in the genus Tetracha (cf. Table 1).

Near Manaus, $M$. s. punctata is found along the Rio SolimõesAmazonas (Ribeiro et al., 1996; cf. Fig. 1) and at the mouth of the Rio Negro. The three larval instars have been de- scribed by Putchkov \& Arndt (1997).

The adult beetles are nocturnal, soildwelling, mostly "running-active" (cf. Adis, 1982), and univoltine. During the terrestrial phase (August/SeptemberMarch/April), they hide aggregated during the day in dry cracks of desiccated lakes as well as under flotsam washed ashore (esp. driftwood, aquatic macrophytes) on the river-and sandbanks. At night they frequently hunt, together with Megacephala spinosa, Megacephala klugi and $M$. aequinoctialis, for soft-bodied terrestrial arthropods on the wet sandbelt along the river. The numerous aquatic insects which occasionally emerge from the river and fly ashore (e.g. Ephemeroptera) are readily fed as well. Potential predators of the three cicindelid species are nocturnal wading birds (probably Bartramia longicauda, Tringa macularia; Petermann, personal communication), and their remains (elytra and head capsules) are frequently found together with fire ants and sand material in the bird pellets on the beach. When disturbed during the day near the water's edge, adult beetles of $M . s$. punctata run into the water where they may hide submerged for several hours (see below). Occasionally they use flight to escape when exposed to the sun on land or when put on the surface of the water. A quiescence of adult beetles in individual burrows along

Table 3. Measurements of larval instars in Megacephala sobrina punctata.

\begin{tabular}{lccc}
\hline & LI & L II & L III \\
\hline Diameter of tunnel opening $(\mathrm{mm})$ & $1.4-3.7$ & $3.8-5.3$ & $5.4-7.4$ \\
Head width of larvae $(\mathrm{mm})$ & $1.60-2.70$ & $2.78-3.15$ & $3.75-4.35$ \\
Body length of larvae $(\mathrm{mm})$ & $9-11$ & $15-21$ & $25-31$ \\
Number of larvae & $n=31$ & $n=31$ & $n=14$ \\
\hline
\end{tabular}


vertical river banks, reported for " $M$. sobrina" from Costa Rica during the rainy season (Wille \& Michener, 1962), was not observed. Larval period of $M$. s. punctata is from September to March. At the mouth of the Rio Negro, up to $20 \mathrm{ind} . / \mathrm{m}^{2}$ were found on the bare beach $4-14 \mathrm{~m}$ from the water margin. The diameter of the tunnel opening (Table 3 ) in the diurnal larvae corresponds with the larger size of the head capsule after each moult and allows an assignment to the three larval stages in species specific colonies in the field. Crumbs of sand, indicating the burrowing activities of larvae inside their tunnel, are found up to $1 \mathrm{~m}$ distant from the openings. The larvae are generalists, and they prey on softbodied arthropods and small Oligochaeta. Large Mutillidae, however, can sting them to death. In case of food shortage, some larvae leave their tunnels at night and forage in close vicinity on the beach surface. During rain events the tunnel openings are closed. Larvae and pupae are not flood tolerant as are Megacephala (P.) $k l u g i$. Thus, in low riverine areas the development of larvae is threatened in years with a fast rising water level. In many cases they try to escape to higher situated beach areas. In the laboratory $\left(27-30^{\circ} \mathrm{C}\right)$, the time of development "egg to beetle" took about 100 days, with $8.2 \pm 2.6$ days observed for the egg stage, $77.5 \pm 10.5$ days for the larval stage and $14.3 \pm 2.9$ days for the pupal stage (Ribeiro et al., 1996). Adult beetles emerge from January onwards. Longevity of adults in the laboratory was up to 14 months. During the period of rising water, they migrate to the higher elevated floodplain forest, move into the trunk and canopy region, or inhabit driftwood, where they hide or live submerged during the day (ecoethological adaptation). In order to renew the air, diving animals walk backwards along the driftwood towards the water surface until the tip of the abdomen is above the water's surface. The respiration procedure only takes a few seconds. The new air is stored in the subelytral cavity under the elytra and serves as a physical gill under water. It is actively ventilated by vertical up and down movements of the abdomen (plastron respiration) and enables extension of the diving time under water (ecophysiological adaptation). Maximum time per diving event is 2 hrs. Frequency and duration of diving varies from animal to animal, increases during starvation but decreases with rising water temperature. The semiaquatic life of adult beetles is favoured by (1) bulgy uprising spiracles with reticulate, microtrichiacovered lateral areas, (2) a high density of hair on the hind wings which face the abdomen and cover the spiracles and (3) elevated lateral margins of the abdomen (morphological adaptation). First data also suggest a gonad dormancy in females during the aquatic phase (see Adis (1982), Adis et al. (1993), Adis \& Messner (1997), Ribeiro et al. (1996) for further information).

\section{Megacephala spinosa}

This medium-sized species (body length $\leq 14 \mathrm{~mm}$ ) is found on sandy beaches and banks of Amazonian rivers. It is 
recorded from Peru, Ecuador, Brazil and Bolivia (cf. Nuñes et al., 1994; Wiesner, 1992). Huber (1994) suggested to place this species in the genus Tetracha (cf. Table 1).

Near Manaus, M. spinosa is found along the Rio SolimonesAmazonas (Ribeiro et al., 1996; cf. Fig, 1) and along the Rio Negro. The three larval instars have been described by Putchkov \& Arndt (1997).

The adult beetles are nocturnal, soil-dwelling, mostly "running-active" (cf. Adis, 1982), univoltine, and of solitary behaviour. During the terrestrial phase (August/September-March/ April), single specimens are found, sometimes together with Megacephala sobrina punctata, hiding during the day in dry cracks of dessicated lakes as well as under flotsam washed ashore (esp. driftwood, aquatic macrophytes) and in individual burrows built before dawn on the river- and sandbanks. When disturbed during the day near the water's edge, adult beetles of $M$. spinosa run inland but never into the water, like $M$. s. punctata, even though their spiracles are morphologically similar and would suggest an ability for diving (cf. Adis \& Messner, 1997). At night they frequently hunt, together with the-other Megacephala species, for soft-bodied terrestrial arthropods on the wet sandbelt along the river (see above). The larvae are diurnal and mostly found in moist sand along the beach. It is unknown in which stage of development $C$. spinosa passes the aquatic phase, and both life cycle and possible adaptations need to be studied.

\section{Odontocheila confusa}

This is the largest species (body length $\leq 13 \mathrm{~mm}$ ) inhabiting primary and secondary floodplain forests of Amazonia. It is recorded from Venezuela, Ecuador, Peru, Colombia, Bolivia and Brazil. Adult beetles are found occurring regularly together with Pentacomia egregia and $P$. lacordairei (cf. Nuñes et al., 1994; Pearson, 1985; Pearson \& Anderson, 1985; Pearson \& Huber, 1995; Rodríguez et al., 1984; Wiesner, 1992).

Near Manaus, $O$. confusa inhabits seasonal white- and mixedwater inundation forests (cf. Fig. 1). The second and third larval instars have been described by Arndt et al. (1996). The adults are diurnal, soil-dwelling, but also "flyingactive" (cf. Adis, 1982), and univoltine.

First data show (Amorim \& Adis, unpublished), that adult beetles pass the aquatic phase of 5-7 months duration in the lower region of tree trunks. During the day, they are observed sitting on leaves of branches close to the water level and flying between them. At night, they frequently come to light sources inside and in front of the inundated forest. A total of 146 adult beetles were caught in March 1990 at the forest fringe of the central lake on Marchantaria Island (cf. Fig. 1) at a white light mounted in a canoe to capture insects (Fonseca \& Vieira, unpublished). Females return to the forest floor to lay their eggs as soon as higher situated areas emerge from the receding flood waters (August/September). The first larval instar is found only four weeks thereafter, all instars are diurnal. Adult beetles of the new generation emerge with the beginning rainy season (from December on- 
wards). During the terrestrial phase (until March/April), adults are best caught by sweeping the low vegetation (e.g. seedlings of trees, herbs) at sunny places on the forest floor. This is where they fly when being disturbed. After heavy rainfalls, adult beetles of Odontocheila confusa are observed, together with $P$. egregia, hunting for adult Diptera, particularly Culicidae (Culex spp., Anopheles spp.) at the edge of temporary water puddles inside the forest. During rising and receding flood waters, both cicindelid species forage for emerging Ephydridae (Discocerina (Lamproclasiopa) nitida Cresson, Discocerini, Diptera; det. W. Mathis) in sunny places close to the water margin at the forest fringe (Adis \& Amorim, personal observation). Pearson $\&$ Anderson (1985) observed that $O$. confusa forms communal nocturnal roosts of up to 175 indiviuals on bushes in floodplain forests of Peru, sometimes at the same place night after night. Individuals sit on the leaf surface with the heads usually up and facing the leaf petiole.

First experiments under simulated flood conditions with young beetles in climate-controlled chambers at Manaus (Amorim \& Adis, unpublished) indicate, that steady temperatures of the air (constant $24^{\circ} \mathrm{C}$ ) favour maturing of gonads in females, compared to alternating air temperatures (day/night: $27 / 21$ or $29 / 24^{\circ} \mathrm{C}$ ). Like in $P$ egregia, gonad development in males is not influenced by air temperatures.

\section{Pentacomia cribrata (Fig. 3a)}

This small species (body lenght $\leq 8 \mathrm{~mm}$ ) is found on sandy and clayey beaches. It is recorded from French Guyana, Venezuela, Peru, Ecuador, Bo- livia, and from northern to southern Brazil (cf. Nuñes et al., 1994; Pearson, 1985; Pearson \& Huber, 1995; Wiesner, 1992).

Near Manaus, $P$. cribrata is found, sometimes together with $C$. suturalis, on sandy or clayey beaches and banks of the Rio Solimões-Amazonas, often on wet sediments. Adult beetles are diurnal, mostly "flying-active" (cf. Adis, 1982) and they forage and copulate at the edge of the water. According to Pearson \& Anderson (1985) adults roost inside the base of leaf sheats of river-edge grass, $25-35 \mathrm{~cm}$ above the ground. On Marchantaria Island the diurnal larvae, still undescribed (Arndt, in preparation), are mainly found in moist, clayey sediments along the beach. First laboratory data indicate, that the development from the egg to the emerging beetle takes only about 2 months, thus might represent an adaptation to rapidly changing conditions at the river edge (Zerm \& Adis, unpublished). It is not known in which stage of development $P$. cribrata passes the aquatic phase and further data on life cycle and adaptations are not available at this time. Possibly two (or more) generations of adult beetles, having emerged during the terrestrial phase, pass the period of inundation. This pattern is observed in a carabid beetle which inhabits mixed- and blackwater inundation forests near Manaus (Adis et al., 1997).

\section{Pentacomia egregia (Fig. 3d,e)}

This small species (body length $\leq 9 \mathrm{~mm}$ ) inhabits floodplain forests, mostly along whitewater rivers, throughout Amazonia. It is recorded 

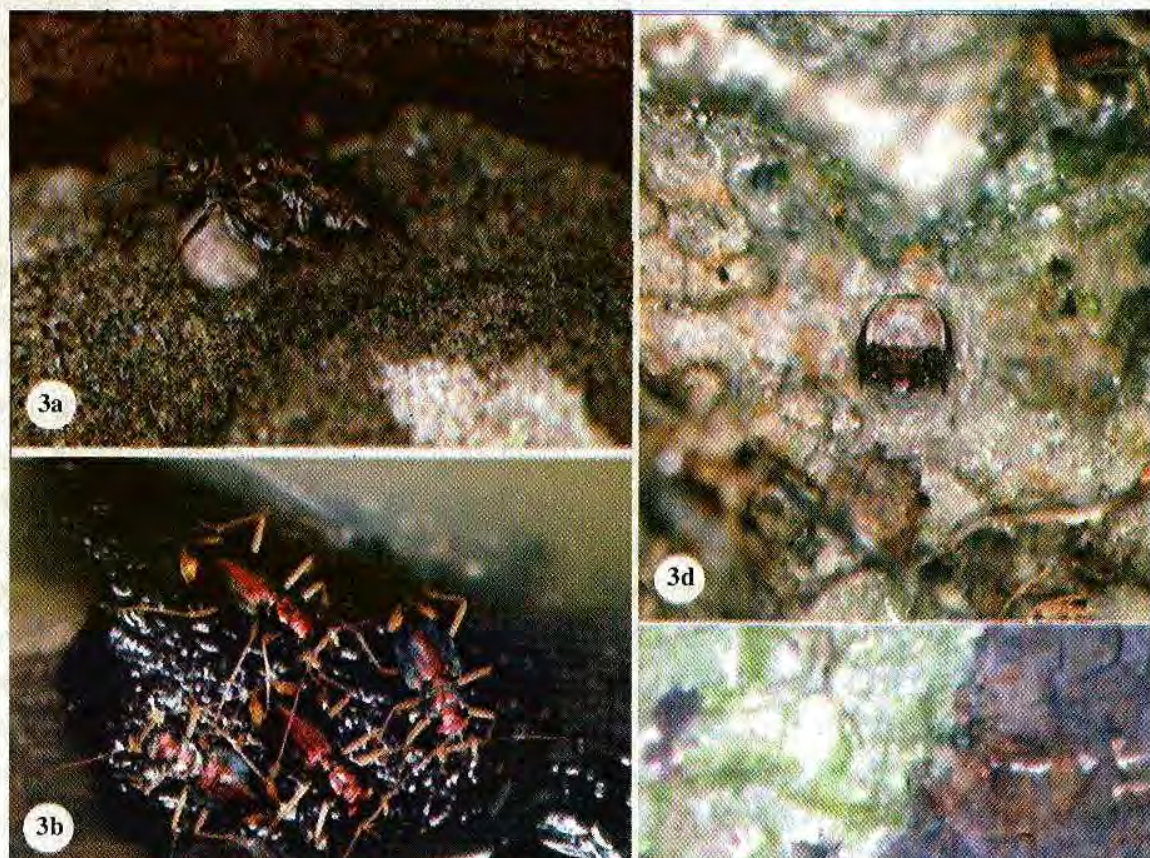

3b
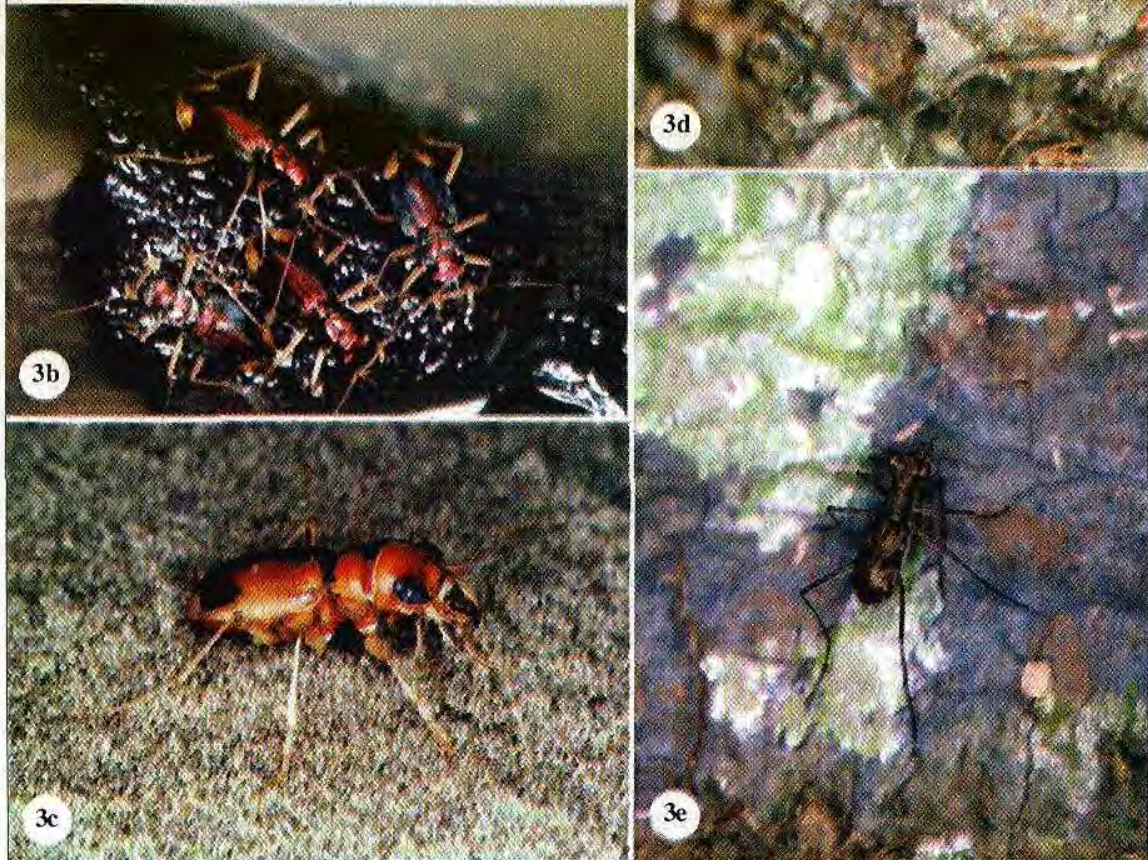

Figure 3. Habitus of selected tiger beetles (Cicindelinae) inhabiting várzea floodpains near Manaus: a) Pentacomia cribrata: female \& male; b) Megacephala sobrina punctata: females and males foraging on floating log at night; c) Megacephala klugi: male; d) Pentacomia egregia: 3rd larval instar; e) Pentacomia egregia: female. Photos: J. Adis (a,b,d,e) \& M. Zerm (c). 
from southern Venezuela, Ecuador, Peru, northern Bolivia and Brazil. Adult beetles are found occurring regularly with Odontocheila confusa and Pentacomia lacordairei (cf. Pearson, 1985; Pearson \& Anderson, 1985; Pearson \& Huber, 1995; Rodríguez et al., 1994; Wiesner, 1992).

Near Manaus, $P$ e egregia inhabits seasonal white- and mixedwater inundation forests (cf. Fig. 1). The three larval instars have been described by Arndt et al. (1996). The adults are diurnal, soildwelling, but also "flying-active" (cf. Adis, 1982), and univoltine.

Adult beetles pass the aquatic phase of 5-7 months duration (March/ April- August/September) in groups, mainly on the lower, shady area of (buttressed) tree trunks above the water level. If put on the water surface, they show a positive scototactic reaction towards broad black areas, corresponding with large tree trunks in the flooded forest. At night, the adults sometimes roost in groups on top of leaves on tree branches extending low over the water surface. Some come to light sources, e.g. of flight traps installed in the lower tree canopy or on boats and houses in front of the inundated forests. Some are obtained by fogging the lower canopy at dawn with aerosol insecticide (cf. Adis, 1997; Erwin, 1983). Males attain gonad maturity earlier than females, copulate with the still immature females and die in the trunk region before the flood water has left the forest. Females store the received spermatophores in their bursa copulatrix and ovaries become mature only when the forest floor begins to dry. Then females return to the ground, deposit their eggs and die. No beetles are active throughout the following $3-4$ months of the terrestrial phase (low-water, dry season), only larvae. The diurnal larvae are generalists and their period of development depends on the amount of available food (cf. Amorim et al., 1997a). Their tunnels are often found on slopes close to the forest fringe where light is more abundant and there is little litter on the ground. They are frequently found clustered at the base of tree trunks. Leaves which occasionally fall on top of the tunnel are perforated and used as a tunnel opening. In the field, adult beetles emerge from January onwards (rainy season), 1-3 months before forest inundation. After heavy rainfalls, adult beetles of $P$. egregia and Odontocheila confusa are observed hunting for adult Diptera, in particular Culicidae (Culex spp., Anopheles spp.) at the edge of temporary water puddles inside the forest. During rising and receding flood waters, both cicindelid species forage for emerging Ephydridae (Discocerina (Lamproclasiopa) nitida Cresson, Discocerini, Diptera; det. W. Mathis) in sunny places close to the water margin at the forest fringe (Adis \& Amorim, personal observation).

$P$. egregia has excellent flight capacity: adult females with mature gonads were spotted during receding waters (September, 1994) on top of a steep river slope on Marchantaria Island. They most likely crossed the Rio Solimões to oviposit. The first larval stage was located in vertical tunnels built in the clayey soil facing the river, just below the grass cover of the surface.

Experiments under simulated 
caudal part of frontale U-shaped, separate from the ridge of vertex (Fig. 7). Gular suture T-shaped (Fig. 8). Median hooks of abdominal tergite $\mathrm{V}$ slender, \pm arched (Figs. 11-20). Pronotum with more or less distinct elevations and often with flattened setae (Figs. 25-34) Antennomeres I and II not obviously wide, less than 2 times wider than antennomere III. (Cicindelini)

4 (5) All setae on median hooks are stout bristles; apical spine of inner hooks comparably long (Figs. 11-18). Labial palpomere II with 1 seta in basal half of the segment. Odontocheila Castelnau, Cenothyla Rivalier and Pentacomia Bates (Larvae of these genera are not to distinguish doubtless at generic level, see Arndt et al., 1996.)

5 (4) Most or all setae of median hooks thin and long; apical spine of inner hooks usually shorter than lateral setae (Figs. 19, 20). Labial palpomere II with 1 seta near the middle of the segment.

Cylindera Westwood and

Brasiella Rivalier (Larvae of both genera can not be distinguished with present knowledge, see Arndt et al., 1996.)

6 (3) Ventral double sclerite on prementum lacking (Fig. 6). Ridge on the caudal part of frontale transverse and joining the ridge of vertex (Fig. 9). Gular suture Y-shaped (Fig. 10). Median hooks of abdominal tergite $V$ straight or only slightly arched, often spine-shaped on the top (Figs. 21-24). Pronotum without distinct elevations and without flattened setae (Figs. 3540) Antennomeres I and II very thick, 3-5 times wider than antennomere III.

(Megacephalini)

7 (8) Pronotum bicolored, medial and anterior parts dark brown with bronze lustre, lateral and posterior margin pearl- white. Setae on pronotum not pale or flattened (Figs. 35, 36). Spine on outer side of maxillary palpomere I lacking.

Aniara Hope

8 (7) Pronotum unicolored, dark, in part with metallic lustre or covered with numerous white and flattened setae (Figs. 37-40). Maxillary palpomere I with strong spine on outer side.

Megacephala Latreille

9 (10) Anterior margin of nasale waved; inner margin of stipes basally with 5-6 spines in third instar larvae and 3-4 spines in second instar larvae; pronotum per half with about 15 long setae and 4050 fine setae in third instar larvae and 20-25 fine setae in second instar larvae (Fig. 37); first instar larvae with 3 setae on antennomere II.

subgenus Phaeoxantha Chaudoir

10 (9) Anterior margin of nasale smooth; in third and second instar larvae inner margin of stipes with $2-4$ spines basally, and pronotum with less setae per half, these long and black (e.g. Tetracha bilunata, see Fig. 39) OR with more than 100 setae, most of them short and white (e.g. Tetracha spinosa, $T$. sobrina, see Fig. 40); first instar larvae with 2 setae on antemnomere II. subgenus Tetracha Hope

\section{ACKNOWLEDGEMENTS}

We thank Prof. Dr. David L. Pearson, Arizona State University, Tempe/USA, Mr. Jürgen Wiesner, Wolfsburg/Germany and Dr. Roger Naviaux, Domérat/France for identification of the cicindelid species and valuable comments on the manuscript. $\mathrm{Dr}$. Laure Desutter-Grandcolas, Muséum National d'Histoire Naturelle, Paris/France, kindly identified the crickets and Dr. 
Wayne Mathis, Smithsonian Institution, Washington, D.C./USA, the shore flies. This study is part of a biodiversity project funded by the German Research Foundation (DFG: Pa. 99/15), the Brazilian Research Foundation (Convênio CNPq/MPG 91.0304-90.4) and the Tropical Ecology Working Group of the Max-Planck-Institute for Limnology (MPL) at Plön/Germany in cooperation with the National Institute for Amazonian Research (INPA) at Manaus/Brazil (Projeto INPA/MAXPLANCK). Dr. Elizabeth Franklin, B.Sc. Rozilete Luniere Guimarães, B.Sc. Tânia Ferreira Hayek, Edilson de Araujo Silva (all formerly Projeto INPA/MAXPLANCK, Manaus/Brazil) as well as Dipl.-Biol. Karsten Holzkamp, Dipl.-Biol. Karsten Heyn, Dipl.-Biol. Philipp Stumpe (all formerly Fachhochschule HildesheimHolzminden/Germany) were a great help in the field and laboratory. Dipl.-Biol. Matthias Zerm (MPIL) is thanked for providing a photograph. Elke Bustorf (MPIL) kindly made the drawings.

\section{Literature cited}

Adis, J. 1982. Zur Besiedlung zentralamazonischer Überschwemmungswälder (Várzea-Gebiet) durch Carabiden (Coleoptera). Arch. Hydrobiol 95(1/4): 3-15.

1992. Überlebensstrategien terrrestrischer Invertebraten in Überschwemmungswäldern Zentralamazoniens. Verh. naturwiss. Ver, Hamburg 33 (NF): 21-114.

1997. Terrestrial invertebrates: Survival strategies, group spectrum, dominance and activity patterns. In: Junk, W.J. (ed). The Central Amazon floodplain. Ecology of a pulsing system. Ecological Studies 126. Springer, Heidelberg.pp. 299-317.

Adis, J.; Amorim, M.A.; Erwin, T.L.; Bauer, T. 1997. On ecology, life history and survival strategies of a wing-dimorphic ground beetle
(Col,; Carabidae: Odacanthini: Colliuris) inhabiting Central Amazonian inundation forests. Stud. Neotrop. Fauna \& Environm. 32(3): 142-192.

Adis, J.; Righi, G. 1989. Mass migration and life cycle adaptation - a survival strategy of terrestrial earthworms in Central Amazonian inundation forests. Amazoniana 11(1): 23-30.

Adis, J.; Schubart, H.O.R. 1984. Ecological research on arthropods in Central Amazonian forest ecosystems with recommendations for study procedures. In: Cooley, J.H.; Goley, F.B. (eds) Trends in ecological research for the 1980s. . NATO Conference Series, Series I: Ecology, Vol. 7. Plenum Press, New York. pp. 111-144

Adis, J.; Messner, B. 1997. Adaptations to life under water: tiger beetles and millipedes. In: Junk, W.J. (ed). The Central Amazon floodplain. Ecology of a pulsing system. Ecological Studies 126. Springer, Heidelberg. pp. 318-330.

Adis, J.; Messner, B.; Hirschel, K., Ribeiro, M.O. de; Paarmann, W. 1993, Zum Tauchvermögen eines Sandlaufkäfers (Coleoptera: Carabidae: Cicindelinae) im Überschwemmungsgebiet des Amazonas bei Manaus, Brasilien. Verh. Westd. Entom. Tag 1992 (Löbbecke-Museum, Düsseldorf); 51-62.

Adis, J.; Morais, J.W. de; Scheller, U. 1996. On abundance, phenology and natural history of Symphyla from a mixedwater inundation forest in Central Amazonia, Brazil. Acta Myriapodologica. (eds. J.J. Geoffroy; J.-P. Mauriès; M. Nguyen Duy-Jacquemin). Mém. Mus, natn. Hist. nat. 169:607-616.

Amaral, I.; Adis, J.; Prance, G.T. 1997. On the vegetation of a seasonal mixedwater inundation forest near Manaus, Brazilian Amazonia. Amazoniana 14(3/4): 301-309.

Amorim, M.A.; Adis, J.; Paarmann, W. 1997a. Life cycle adaptations of a diurnal tiger beetle (Coleoptera, Carabidae, Cicindelinae) to conditions on Central Amazonian floodplains. In: Ulrich, H. (ed). Tropical Biodiversity and Systematics, pp. 233-239. Proceedings Int. Symp. on Biodiversity and Systematics in Tropical Ecosystems, Bonn, 1994. Zoologisches Forschungsinstitut und 
Museum Koenig. 357 pp.

1997b. Ecology and adaptations of the tiger beetle Pentacomia egregia (Chaudoir) (Cicindelinae: Carabidae) to Central Amazonian floodplains. Ecotropica, 3(2): 71-82.

Arndt, E. 1993. Phylogenetische Untersuchungen larvalmorphologischer Merkmale der Carabidae (Insecta: Coleoptera). Stuttgarter Beiträge zur Naturkunde, A, 488: 1-56.

Arndt, E.; Paarmann, W.; Adis J. 1996. Description and key of larval Cicindelidae from Brazil (Coleoptera: Caraboidea). Acta Zool. Bohem., 60: 293-315.

Erwin. T.L. 1983. Beetles and other insects of tropical forest canopies at Manaus, Brazil, sampled by insecticidal fogging. In: Sutton, S.L.; Whitmore, T.C.; Chadwick, A.C. (eds). Tropical rain forest: Ecology and management. (eds. pp. 59-75. Proc. Trop. Rain Forest Symp. Leeds 1982 , Blackwell, Oxford. 498 pp.

Freitag, R.; Barnes, B.L. 1989. Classification of Brazilian species of Cicindela and phylogeny and biogeography of subgenera Brasiella, Gaimara new subgenus, Plectographa and South American species of Cylindera (Coleoptera: Cicindelidae). Quaestiones Entomol. 25(3): 241-386.

Harada, A.Y; Adis, J. 1997. The ant fauna of tree canopies in Central Amazonia: a first assessment. In: Stork, N.E.; Adis, J., Didham, R.K. (eds) Canopy arthropods. Chapman \& Hall, London. pp. 382-400.

Hudson, W.G.; Frank, J.H.; Castner, J.L. 1988. Biological control of Scapteriscus spp. mole crickets (Orthoptera: Gryllotalpidae) in Florida. Bull. Ent. Soc. Am., 34: 192-198.

Huber, R.L. 1994. A new species of Tetracha from the west coast of Venezuela with comments on genus level nomenclature. Cicindela, 26(3/4): 49-75.

Irmler, U. 1973. Population-dynamic and physiological adaptation of Pentacomia egregia Chaud. (Col. Cicindelidae) to the Amazonian inundation forest. Amazoniana, 4(2): 219-227.

Irion, G.; Adis, J.; Junk, W.J.; Wunderlich, F, 1983. Sedimentological studies of the "Ilha de Marchantaria" in the Solimões/Amazon
River near Manaus. Amazoniana 8(1): 1-18. Junk, W.J. 1997. (ed.). The Central Amazon floodplain. Ecology of a pulsing system. Ecological Studies 126. Springer, Heidelberg. $525 \mathrm{pp}$.

Junk, W.J.; Bayley, P.B.; Sparks, R.E. 1989. The flood pulse concept in river floodplain systems. Can. Spec. Publ. Fish. Aquat. Sci. 106; 110-127.

Klinge, H.; Adis, J.; Worbes, M. 1995. The vegetation of a seasonal várzea forest in the lower Solimōes River, Amazon region of Brazil. Acta Amazonica 25(3/4): 201-220.

Linsenmair, K.E.1990. Tropische Biodiversität: Befunde und offene Probleme. Verhandlungen der Deutschen Zoologischen Gesellschaft 83: 245-261.

Morais, J.W. de; Adis, J.; Mahnert, V;; BertiFilho, E. 1997a. Abundance and phenology of Pseudoscorpiones (Arachnida) from a mixedwater inundation forest in Central Amazonia, Brazil. Revue suisse Zool. 104(3): 475-483.

Morais, J.W. de; Adis, J.; Berti-Filho, E.; Pereira, L.; Minelli, S.; Barbieri, F. 1997b. On abundance, phenology and natural history of Geophilomorpha from a mixedwater inundation forest in Central Amazonia. In: Enghoff, H.(ed). Many-legged animals - A collection of papers on Myriapoda and Onychophora. Ent, scand. Suppl. 51: 115-119.

Nuñez, V; Onore, G.; Pearson, D.L. 1994. Los escarabajos tigre del Ecuador (Coleoptera: Cicindelidae), lista de especies y clave para generos. Revista de La Pontifica Universidad Católica del Ecuador 22(58): 57-67.

Paarmann, W.; Irmler, U.; Adis, J. 1982. Pentacomia egregia Chaud. (Carabidae, Cicindelinae), a univoltine species in the Amazonian inundation forests. The $\mathrm{Co}$ leopterists Bulletin, 36(2): 183-188.

Paarmann. W.; Adis, J.; Lüdecke, K.; Tobaschus, N.; Fonseca, C.R.V. da 1998. Spatial and temporal distribution of a tiger beetle guild (Coleoptera: Carabidae: Cicindelinae) along a $105 \mathrm{~m}$ long transect in the Reserva Florestal A. Ducke near Manaus (Central Amazonia). 
Acta Amazonica, 28(3): 331-344

Pearson, D.L. 1985. The tiger beetles (Coleoptera: Cicindelidae) of the Tambopata Reserved Zone, Madre de Dios, Peru. Rev. per. Ent. 27:15-24.

..... 1988. Biology of tiger beetles. Ann. Rev. Entomol.33: 123-147.

Pearson, D.L.; Anderson, J.J. 1985. Perching heights and nocturnal communal roosts of some tiger beetles (Coleoptera: Cicindelidae) in southeastern Peru. Biotropica 17(2): 126-129.

Pearson, D.L; Cassola, F. 1992. World-wide species richness patterns of tiger beetles (Coleoptera: Cicindeliae): Indicator taxon for biodiversity and conservation studies. Conservation Biology 6: 376-391.

Pearson, D.L.; Huber, R.L. 1995. The tiger beetles of Pakitza, Madre de Dios, Peni: Identification, natural history and a comparison to the Peruvian fauna. Cicindela 27(1-2): 1-28.

Penny, N.D.; Arias, J.R. 1982. Insects of an Amazon forest. Columbia University Press, New York. 269 pp.

Prance, G.T. 1979. Notes on the vegetation of Amazonia III. The terminology of Amazonian forest types subject to inundation. Brittonia 31: 26-31.

1990. The floristic composition of the forests of central Amazonian Brazil. In: Gentry, A.H. (ed). Four Neotropical Rainforests. Yale University Press, New Haven. pp. 159-174.
Putchkov, A. V.; Arndt, E. 1994. Preliminary list and key of known tiger beetle larvae (Coleoptera, Cicindelidae) of the world. Bull. Soc. Entomol. Suisse 67: 411-420.

1997. Larval taxonomy of Megacephala (Coleoptera, Cicindelidae). Beitr. Entomol. 47 (1): 55-62.

Ribeiro, M. de N.G.; Adis, J. 1984. Local rainfall variability - a potential bias for bioecological studies in the Central Amazon. Acta Amazonica 14(1/2): 159-174.

Ribeiro, M.O. de A.; Fonseca, C.R.V. da; Foronda, E.H. 1996. Bionomia de Megacephala sobrina punciata Laporte 1835 e inventário das espécies do gênero Megacephala Latreille (Coleoptera: Cicindelidae) em áreas alagáveis na Amazônia Central. Rev. UA. Série: Ciências Biológicas 1(1): 31-54.

Rodriguez, J.P.; Joly, L.J.; Pearson,D.L. 1994. Los escarabajos tigre (Coleoptera: Cicindelidae) de Venezuela: Su identificación, distribución e historia natural. Boletín de Entomologia Venezuelana N.S. 9(1): 55-120.

Ruokaleinen, K.; Tuomisto, H.; Ríos, R.; Torres, A,; García, M. 1994. Comparacion floristica de doce parcelas en bosque de tierra firme en la Amazonia Peruana. Acta Amazonica 41(1/2): 31-48.

Wiesner, J. 1992. Verzeichnis der Sandlaufkäfer der Welt. - Checklist of the tiger beetles of the world. E. Bauer, Keltern. 364 pp.

Wille, A.; Michener, C.D. 1962. Inactividad estacional de Megacephala sobrina Dejean (Coleoptera, Cicindelidae). Rev. Biol. Trop. 10(2): 161-165. 


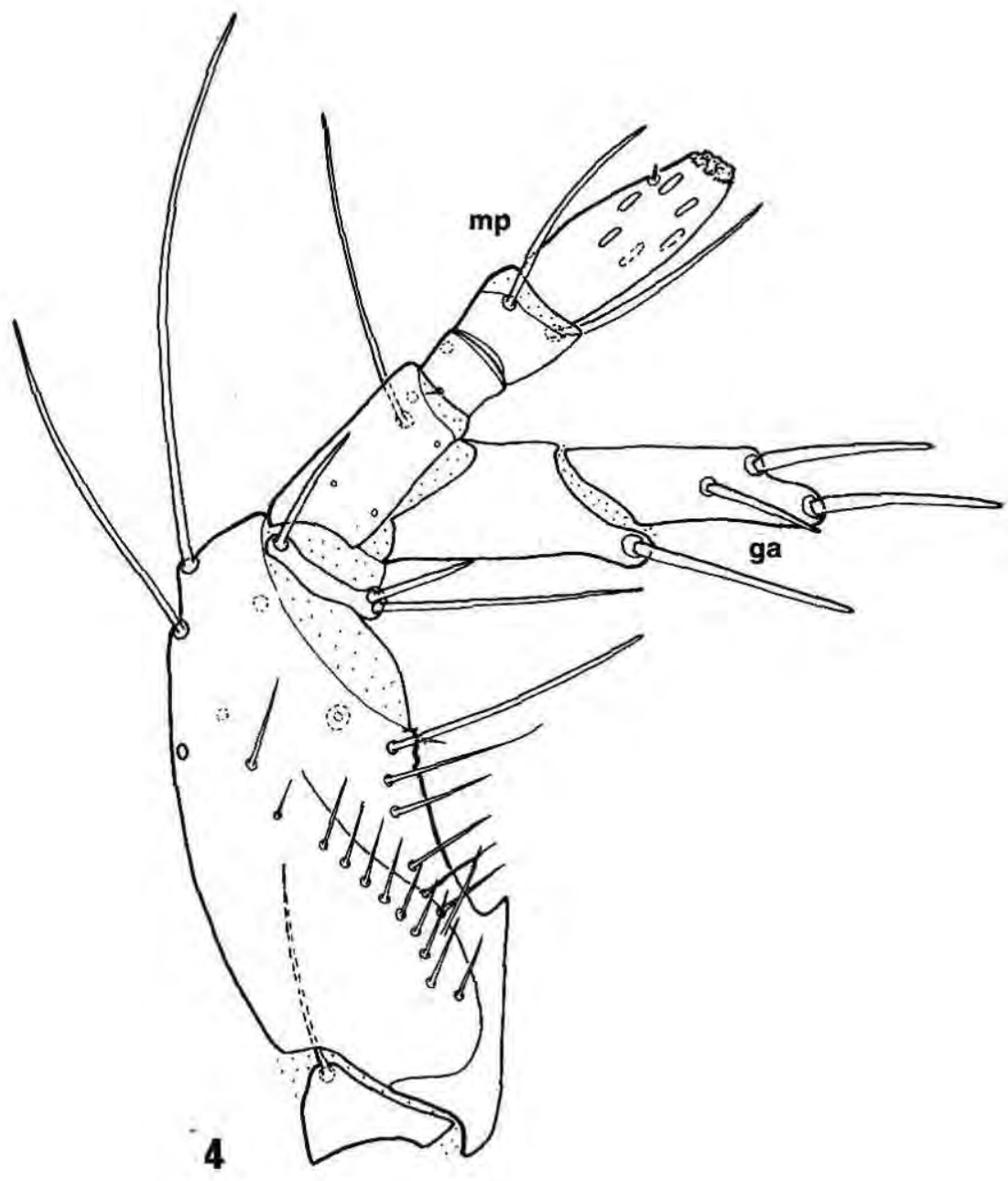

Figure 4. Cicindela spec., first instar, maxille, ventral aspect; ga - galea, mp - maxillary palpus (redrawn from Arndt, 1993). 


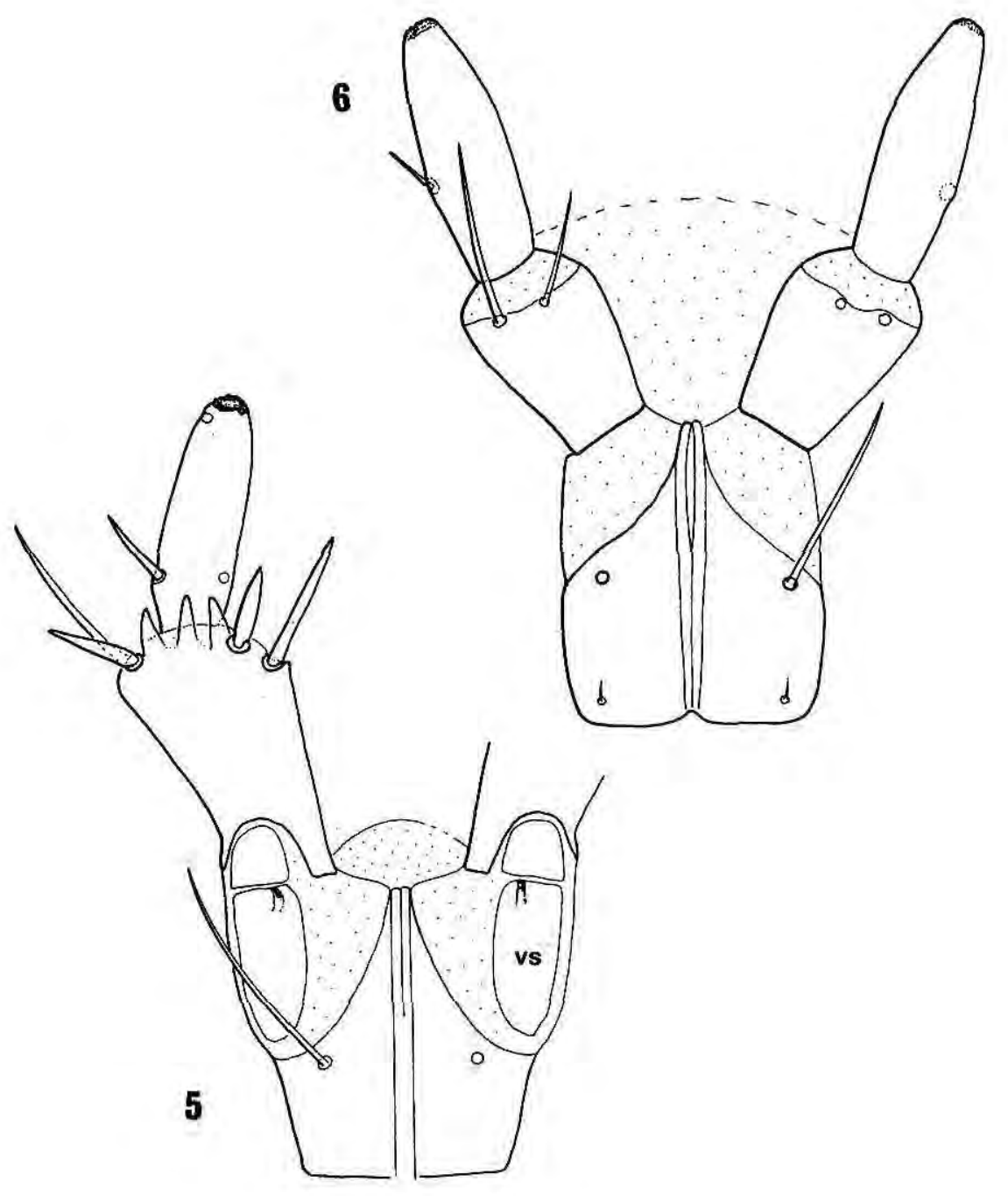

Figures 5, 6. Labium, ventral aspect, instar III. Fig. 5. Cenothyla varians; vs - ventral double sclerite; Fig. 6. Aniara sepulcralis (redrawn from Arndt et al., 1996). 

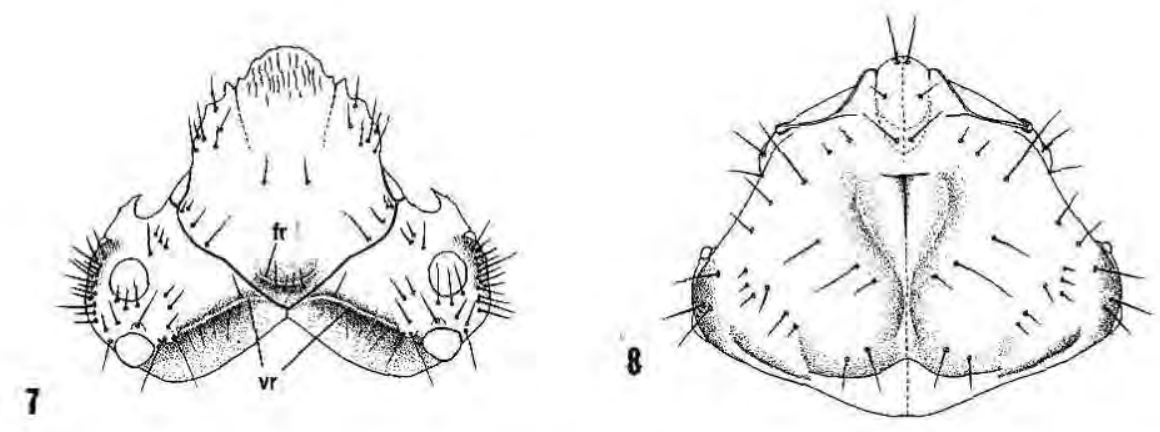

Figures 7, 8. Head of Cicindela spec., instar III, dorsal and ventral aspect; fr - frontal ridge, vr - ridge of posterior part of vertex (redrawn from Putchov; Arndt, 1994).
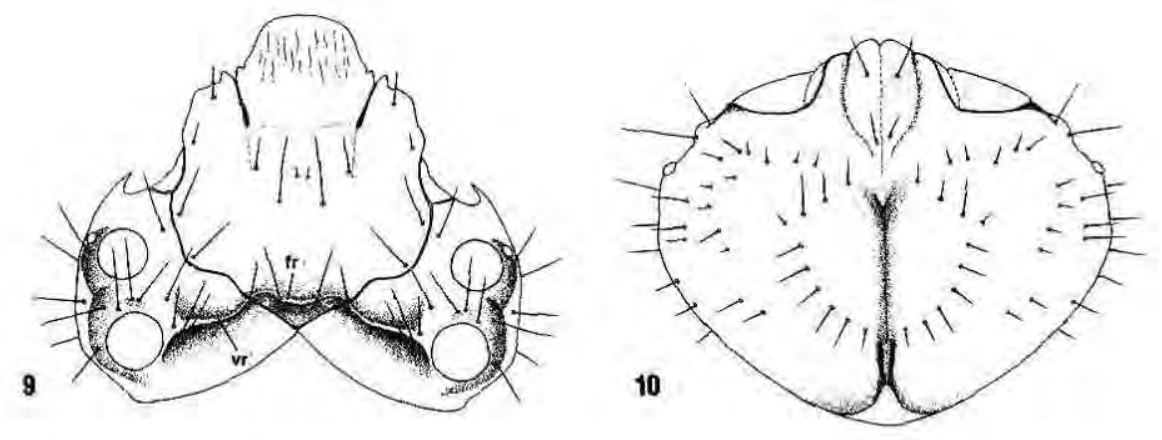

Figures 9, 10. Head of Megacephala spec., instar III, dorsal and ventral aspect; fr - frontal ridge, vr - ridge of posterior part of vertex (redrawn from Putchkov \& Arndt, 1994). 

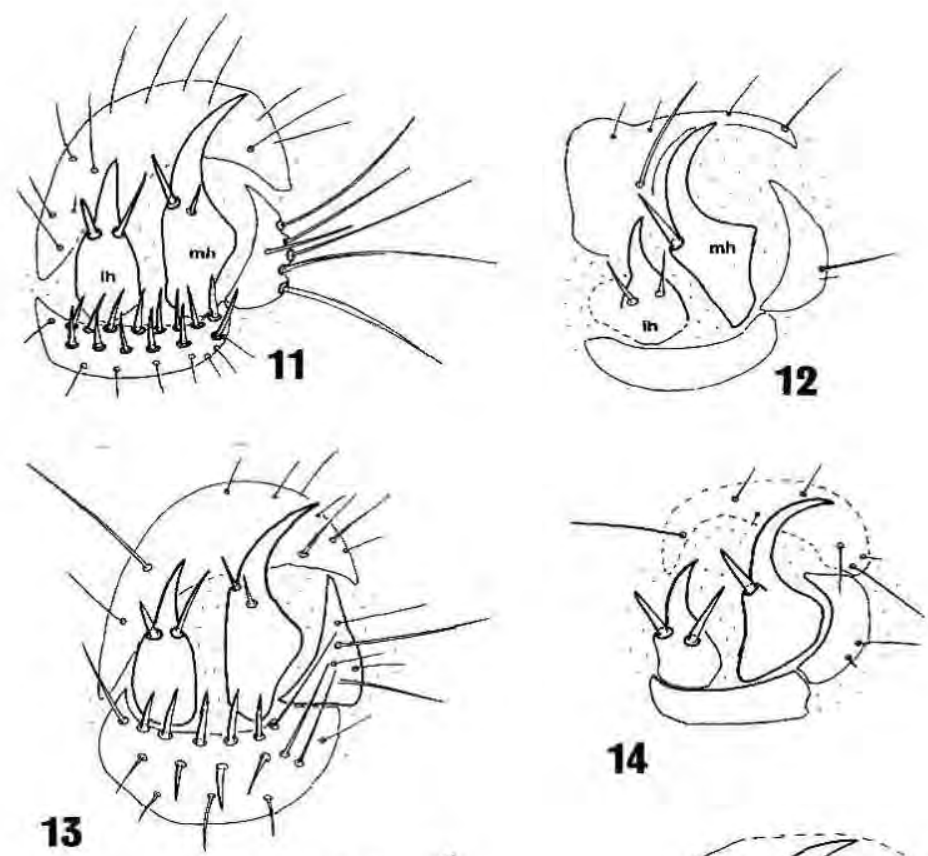

14
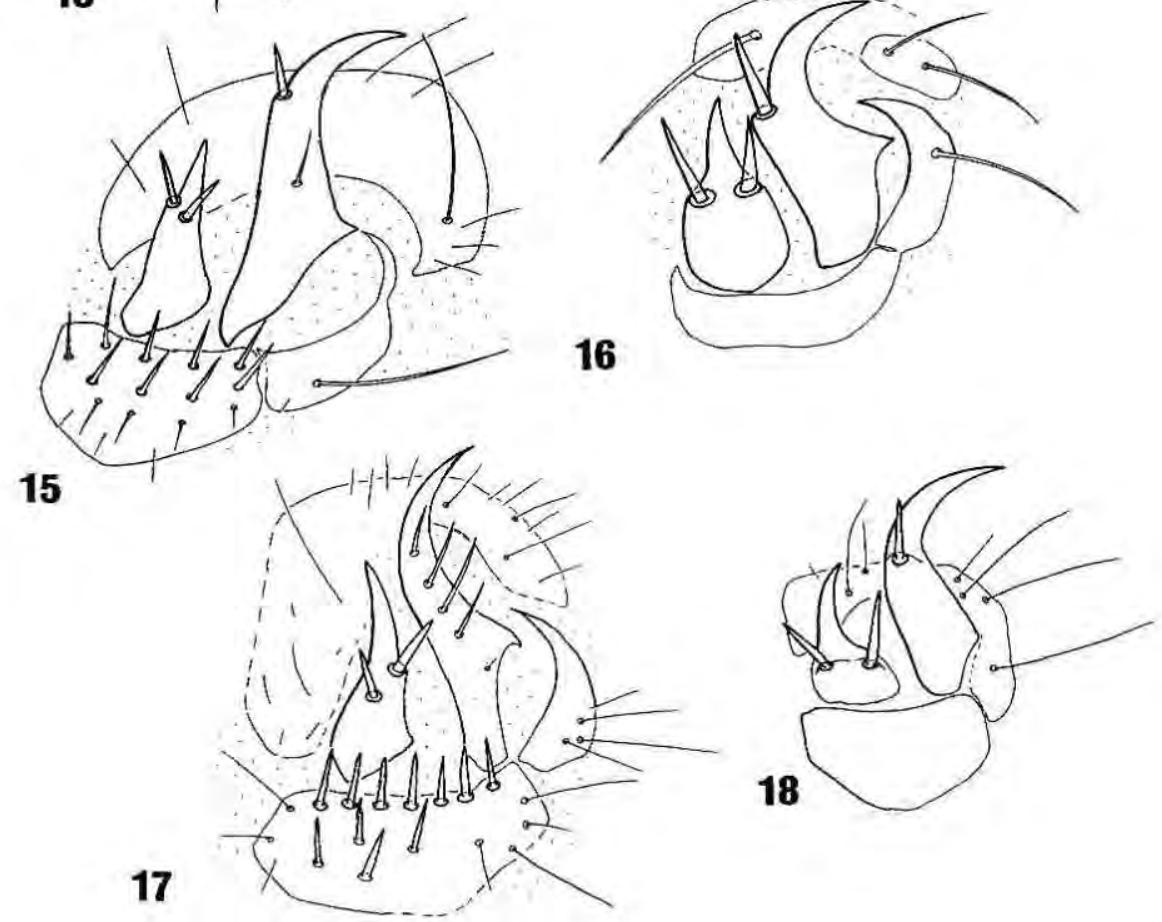

Figures 11-18. Abdominal tergite V, right side (redrawn from Arndt et al., 1996). Figs. 11, 12. Odontocheila cayennensis, instars III and I; ih-inner hook, mh-median hook; Figs. 13, 14. Cenothyla varians, instars III and I; Figs. 15, 16. Pentacomia egregria, instars III and I; Figs. 17, 18. Pentacomiaventralis, instars III and I. 

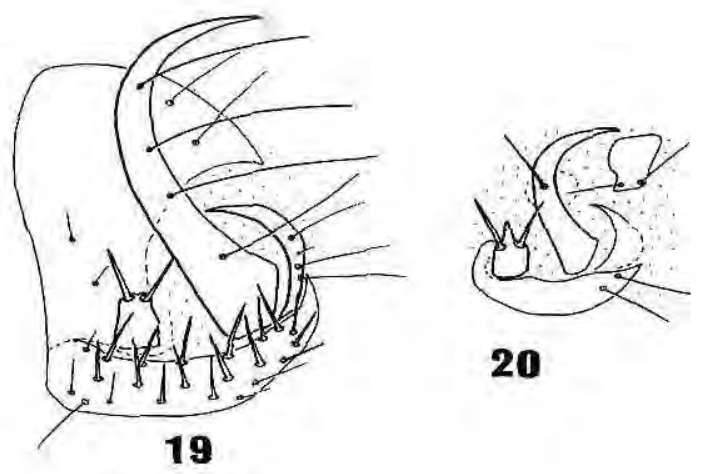

21

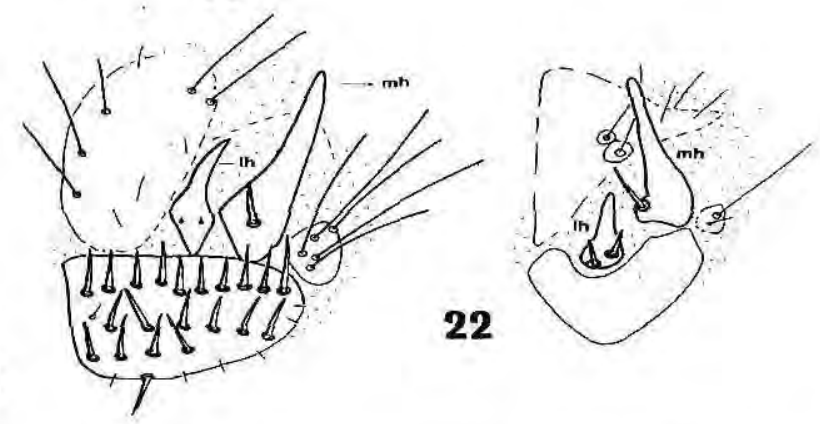

Figures 19-22. Abdominal tergite V, right side (redrawn from Arndt et al., 1996). Figs. 19, 20 Cylindera suturalis, instars III and I; Figs. 21, 22 Aniara sepulcralis, instars III and I; ih-inner hook, mh-median hook.
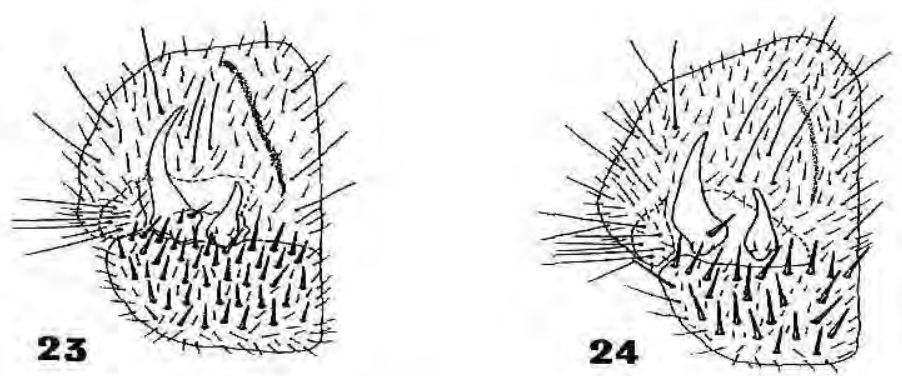

Figures 23, 24. Abdominal tergite V, third instar, left side (redrawn from Putchkov \& Arndt, 1997). Fig. 23. Megacephala (Phaeoxantha) klugi; Fig. 24. Megacephala (Tetracha) bilunata. 

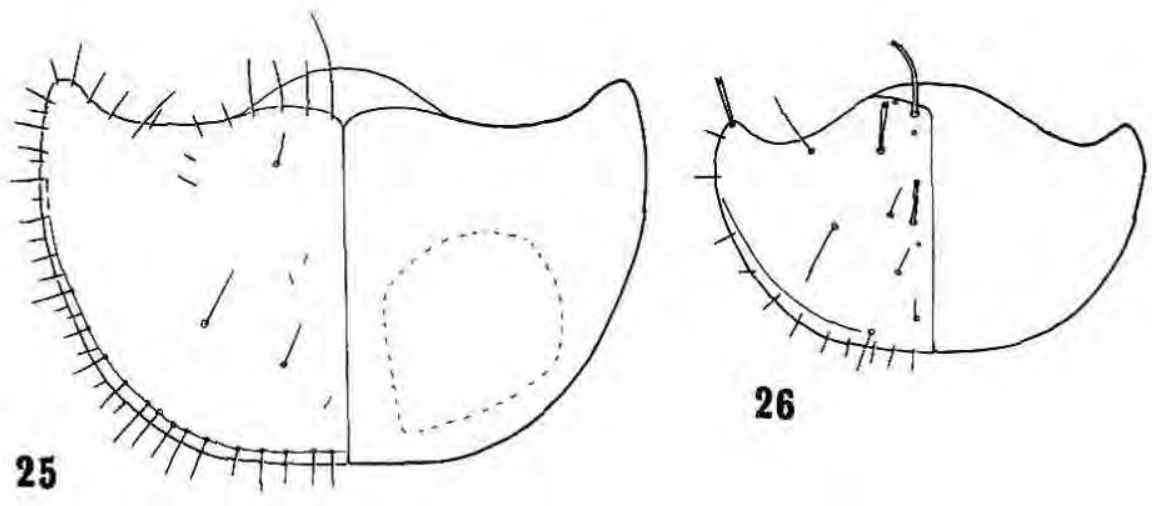

\section{6}
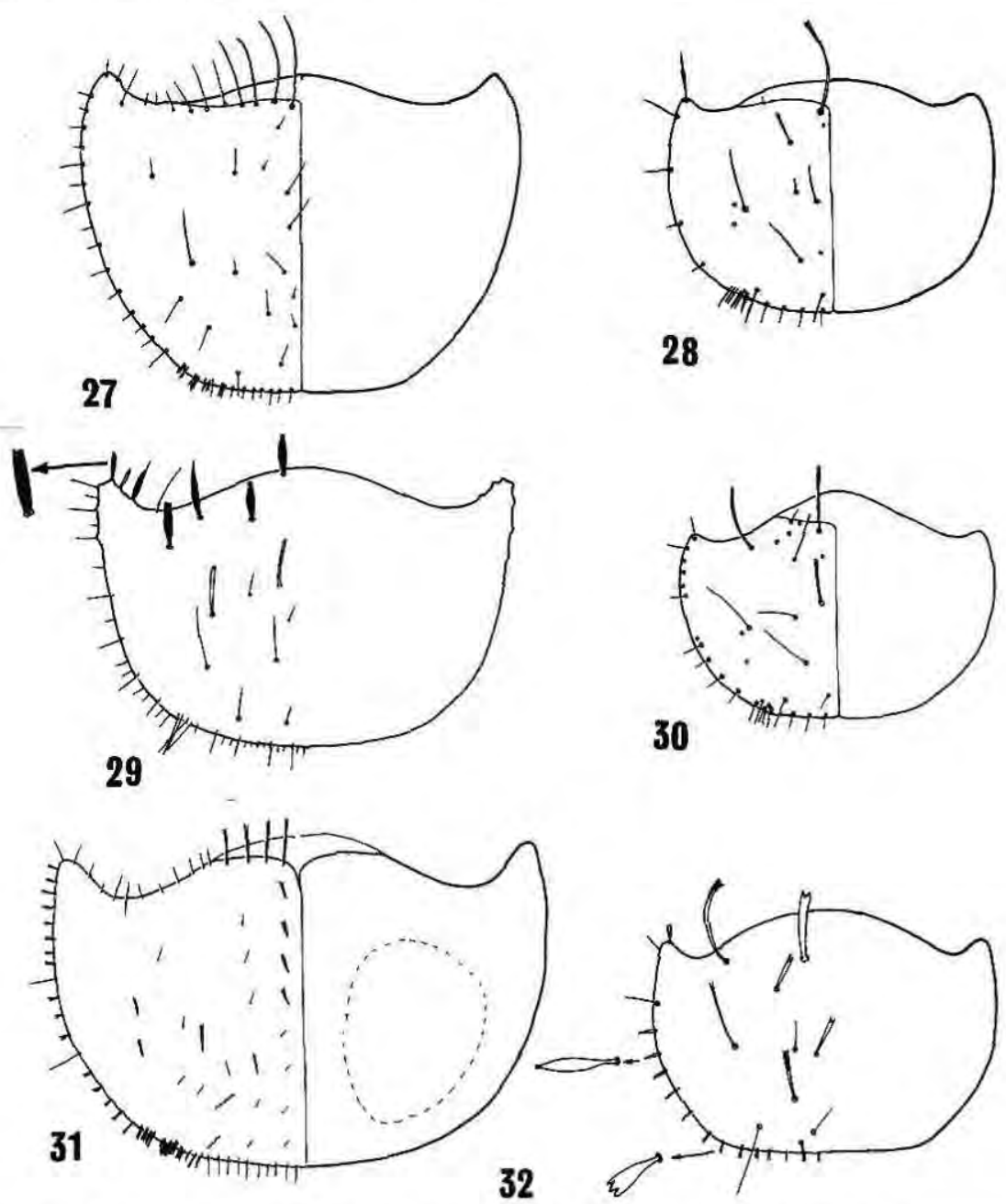

Figures 25-32. Pronotum (redrawn from Arndt et al., 1996). Figs. 25, 26. Odontocheila cayennensis instars III and I; Fig. 27, 28. Cenothyla varians, instars III and I; Fig. 29, 30. Pentacomia egregria, instars III and I; Fig. 31, 32. Pentacomia ventralis, instars III and I. 

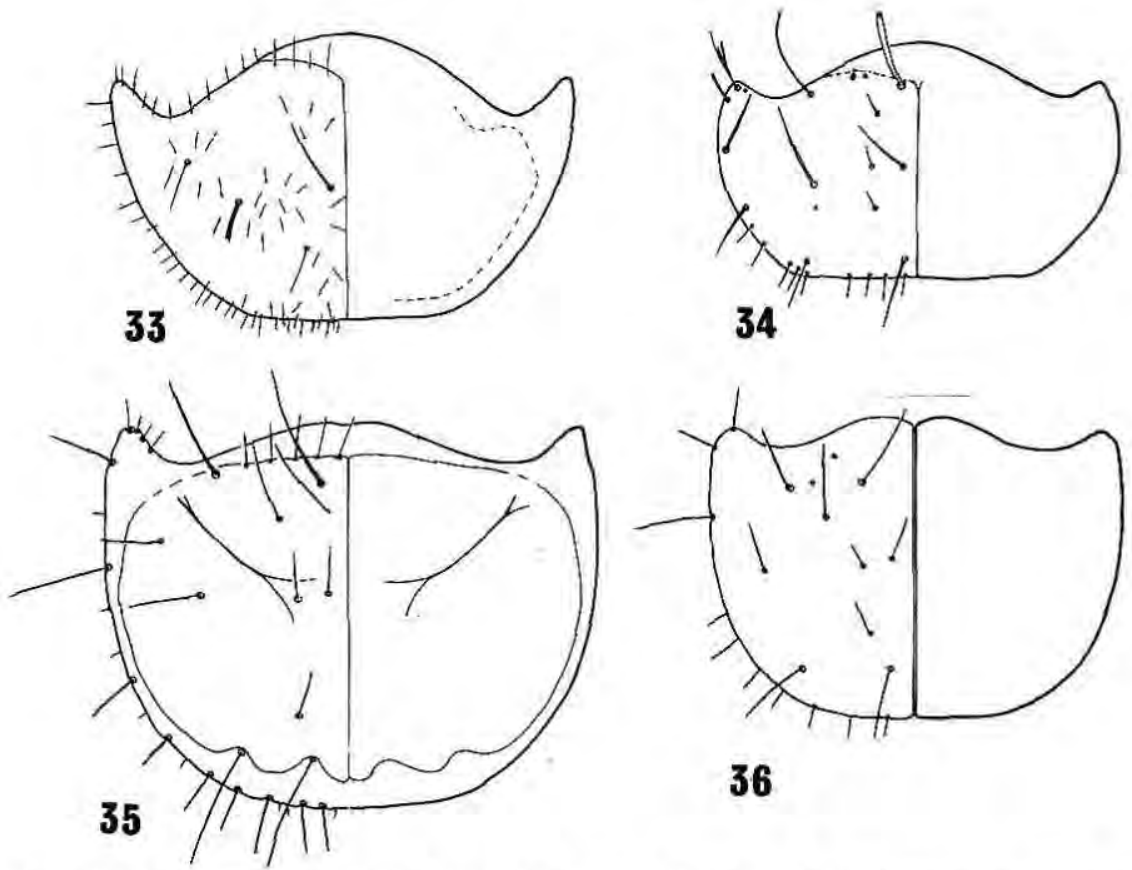

36

Figures 33-36. Pronotum (redrawn from Arndt et al., 1996). Figs. 33, 34. Cylindera suturalis, instars III and I; Fig. 35, 36. Aniara sepulcralis, instars III and I.
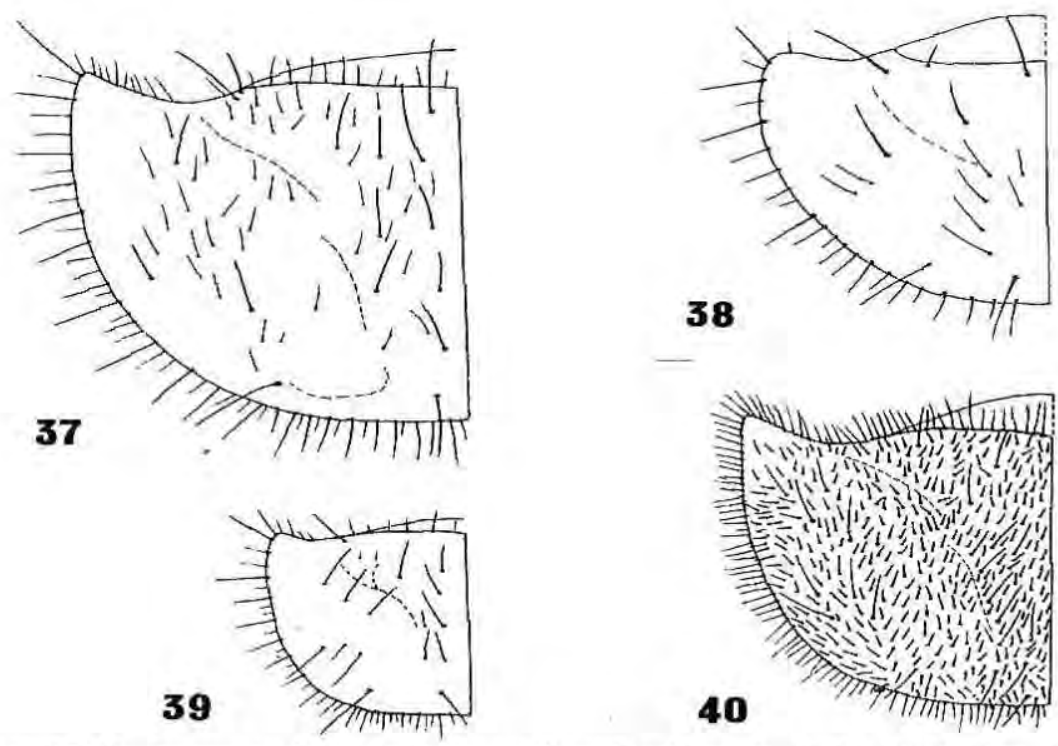

Figures 37-40. Pronotum, left side (redrawn from Putchkov \& Arndt, 1997). Figs. 37, 38. Megacephala (Phaeoxantha) klugi, instars III and I; Fig. 39. Megacephala (Tetracha) bilunata, instar III; Fig, 40. Megacephala (Tetracha) sobrina, instar III. 